\title{
The Bill of Rights Debate in Australia - A Study in Constitutional Disengagement
}

\author{
Bede Harris \\ Faculty of Law, University of Canberra \\ Canberra ACT 2601, Australia \\ Tel: 61-2-6201-2969Ｅ-mail: Bede.Harris@canberra.edu.au
}

\begin{abstract}
The Commonwealth (federal) government of Australia has launched a National Human Rights Consultation process to determine whether human rights in Australia are protected adequately and, if not, what measures should be taken to enhance human rights protection. The Australian Constitution protects only a few rights and contains no comprehensive Bill of Rights. The current debate is anti-theoretical and has been characterised by absolute faith in democracy and a misunderstanding of the nature of a Bill of Rights and what effect it would have on the relationship between the courts and the legislature. The public's lack of knowledge about constitutional matters has been exploited by elements of the conservative press who oppose enhanced rights protection. The conclusion is that ultimately progress in relation to human rights depends on improved civics education.
\end{abstract}

Keywords: Rights, Liberties, Australia, Constitution, Law, Democracy, Civics

\section{Introduction}

On 10 December 2008 - World Human Rights Day - the Commonwealth government of Australia announced that it would initiate a National Human Rights Consultation (NHRC) process. (Note 1) That process has now begun. According to the Consultation's Terms of Reference, its purpose is to consult widely with the public and to ascertain its views on the following questions:

- Which human rights (including corresponding responsibilities) should be protected and promoted?

- Are these human rights currently sufficiently protected and promoted?

- How could Australia better protect and promote human rights?

After receiving the report, the government will determine what, if any, legislative changes should be made to human rights law. The purpose of this article is to comment on the state of the human rights debate in Australia and on its implications for legislative reform. Part 2 of the article explains the constitutional background against which the NHRC process is taking place. Part 3 examines current protection of human rights, while Part 4 considers the attempts that have been made to incorporate a Bill of Rights into the Constitution, culminating in the establishment of the NHRC. Part 5 examines the way the human rights debate has been conducted in Australia, focussing in particular on its anti-theoretical nature and the role played by the conservative press, against the background of a public which is poorly informed about constitutional matters. The article concludes with Part 6, which offers some predictions as to what the outcome of the NHRC process might be and, irrespective of that outcome, what lessons the process has to offer in relation to civics education in Australia.

\section{The constitutional background}

The Commonwealth Constitution forms the Schedule to the Commonwealth of Australia Constitution Act 1900 (UK), and came into force on 1 January 1901. The Constitution established a federal system. As originally conceived, Australia's federation was to be like that of the United States, with the powers of the federal government defined, and thus limited (Joseph and Castan, 2006, p.12). Reserve powers were top remain with the six former colonies that became States in the new federation. (Note 2) Seats in the lower house of the Australian Parliament, the House of Representatives, are allocated to the States in proportion to their populations, while seats in the Senate are allocated equally to each State. (Note 3) The Constitution makes it clear that the Senate is as powerful as the House of Representatives, and it can block any legislation, including financial legislation. (Note 4) Aside from the six States, Australia has numerous Territories, over which the Commonwealth Parliament has plenary legislative power. (Note 5) Most of these are external to continental Australia, but the two most significant are the continental Territories - the Northern Territory (NT) and the Australian Capital Territory (ACT), both of which have been granted self-government and have their own elected Legislative Assemblies, whose laws are vulnerable to Commonwealth over-ride. (Note 6) Both the NT and the ACT are also represented in the House of Representatives and the Senate. 
Amendment of the Constitution is governed by s 128, which requires that after being passed by Parliament, amendments receive the approval of a majority of voters nationwide, plus a majority in a majority of States - which means in four of the six States. (Note 7) Constitutional amendment has proved to be extremely difficult. Of 44 amendments proposed since 1901, only eight have been successful, and most of these have been of a minor, technical nature. Widespread lack of knowledge about the Constitution has made them profoundly suspicious of change, and history shows that amendments are doomed to failure unless they are uncontroversial and are supported by both the main political parties - Liberal and Labor. (Note 8)

The topics over which the Commonwealth Parliament has legislative capacity are mostly specified in s 51 of the Constitution, which enumerates thirty-nine heads of power (hence they are usually referred to as the 'enumerated powers'). In addition, Commonwealth legislative powers are specified haphazardly in several other sections of the Constitution. (Note 9) Of the Commonwealth's legislative powers, only a few are exclusive - in other words, are matters upon which the States cannot legislate. (Note 10) The vast majority are thus concurrent, and the States may use the plenary powers they enjoy under their Constitutions to enact laws on matters upon which the Commonwealth has legislative competence. Only if the Commonwealth has enacted a law on a topic lying within its legislative competence, and that law is inconsistent with a law of a State, will the State law be over-ridden by virtue of the inconsistency provision contained in $\mathrm{s} 109$ of the Constitution.

However, although this may be the theory, in practice the constitutional balance has swung increasingly in favour of the Commonwealth. The start of this process was the decision by the High Court (which lies at the apex of the Australian judicial system and is the ultimate court of appeal on both Commonwealth and State matters) in Amalgamated Society of Engineers $v$ Commonwealth (Note 11) in which the court abandoned its interpretative approach based on the reserve powers doctrine, and announced that it would instead interpret Commonwealth legislative powers with the full amplitude of meaning that they could bear. This fundamental change in the interpretation of the Constitution is usually explained as a consequence of the changing personnel of the court, most of the initial Justices who had been members of the court at its inception no longer being on the bench by 1920 (Hanks, Keyzer and Clarke, 2004, p. 570-578). Broad interpretation of Commonwealth powers over taxation (which, the court held, can be used to induce or deter behaviour) (Note 12) and over corporations (any aspect of the activities of which, including labour relations, can be legislated on by the Commonwealth) (Note 13) has led to the situation where there is much less activity that is beyond the reach of the Commonwealth (and thus from which the States cannot be expelled) than the drafters of the Constitution envisaged. In addition to this, the apparently beneficial power that the Commonwealth has under s 96 of the Constitution to make grants to the States is subject to the rider that grants can be subject to any terms the Commonwealth sees fit, and this has been used by the Commonwealth to induce the States to do things that are beyond the legislative capacity of the Commonwealth. This is made possible by the fact that there is severe fiscal imbalance within the federation, as the Commonwealth monopolises income tax and the States are prohibited by s 90 of the Constitution from imposing taxes on goods, with the result that, as an aggregate, the States depend on Commonwealth grants for $44 \%$ of their income (Harris, 2002, p. 136).

\section{Human rights protection}

So far as human rights are concerned, protection could best be described as patchy. Australia has no Bill of Rights. The Commonwealth Constitution protects a handful of express rights to a jury trial for indictable Commonwealth offences (s 80), to freedom of inter-State trade, commerce and intercourse (s 92), to freedom of religion under Commonwealth law (s 116), to non-discrimination on grounds of residence in a State (s 117) and to just terms compensation when property is acquired (s 51(xxxi)). All of these reflected particular social and political concerns on the part of the six colonies at the time of federation. They were obviously not an attempt to draft a Bill of Rights. Apart from the express rights, the High Court has recognised an implied freedom of political communication, (Note 14) an implied right to vote (Note 15) and a right not to be deprived of personal liberty without due process. (Note 16)

State Parliaments have the capacity to impose procedural restraints on themselves, (Note 17) and so could enact entrenched Bills of Rights, however none has done so. Some protection of human rights is afforded by (unentrenched) State and Territory anti-discrimination laws. However, these laws obviously protect only one right - that to equality and are subject to legislative over-ride by subsequent inconsistent legislation by virtue of the common law doctrine of parliamentary sovereignty.

The Commonwealth too has enacted laws prohibiting discrimination on grounds of race, gender and disability. (Note 18) However, none of these is entrenched and indeed could not be without amendment of the Constitution, as ss 1, 23, 40 and 51 of the Constitution prevent the Commonwealth Parliament from placing restraints, either procedural or substantive, on its own legislative power. Thus, s 10(1) of the Racial Discrimination Act 1975 (Cth), which states that all legislation, including subsequent legislation, is invalid to the extent that it is inconsistent with the Act, is not entrenched and can be over-ridden by express legislation to the contrary, as indeed happened recently when the Commonwealth enacted legislation imposing controls on Indigenous communities in the Northern Territory. (Note 19) 
The closest any Australian jurisdictions has come to the enactment of a document affording comprehensive protection to human rights are those enacted by the Australian Capital Territory and by Victoria - the Human Rights Act 2004 (ACT) and the Charter of Rights and Responsibilities Act 2006 (Vic). In essence, these documents are an interpretative aid, requiring the courts to interpret legislation consistently with the document where possible, (Note 20) expressly stating that where this is not possible the legislation must be applied, (Note 21) while allowing the courts to make a declaration of incompatibility where that is the case. (Note 22) Although public authorities are bound to respect human rights, that obligation succumbs in the face of legislation which cannot be interpreted consistently with the human right s statutes. (Note 23) Furthermore, the right to recover damages for breaches of rights by public authorities in those instances where statutes are able to be interpreted consistently with human rights, is specifically excluded. (Note 24)

\section{Previous attempts at enhanced human rights protection}

As mentioned above, constitutional reform has had an unsuccessful history in Australia. The last occasion in which the Constitution was amended in such a way as to affect fundamental rights was in 1967, when the power to make laws 'for people of any race' in s 51(xxvi) was amended so as to remove a limitation on the powers of the Commonwealth Parliament which had permitted the States to block the extension of franchise rights to Aboriginal people.

In 1988 a major inquiry into the Australian Constitution recommended that a Bill of Rights be incorporated into the Constitution (Constitutional Commission, 1988, paras 9.13, 9.75 and 9.139). Very few of the Commission's recommendations were acted upon, but a referendum was held in 1988 in which voters were asked to approve relatively minor extensions to existing Constitutional rights so as to broaden the circumstances in which trial by jury is required, to extend the right to freedom of religion so as to govern State and Territory law and to broaden the scope of the right to compensation when property is acquired so as to cover acquisitions by the States and Territories. These propositions were comprehensively rejected.

In 2000, separate Bills were introduced into Parliament by the (now defunct) Australian Democrats party and by an independent MP to enact the International Covenant on Civil and Political Rights (Note 25) into domestic law. Both Bills failed.

The current Labor government, elected in 2007, has manifested greater interest in constitutional reform than its predecessors of either party. In June 2008 the House of Representatives Standing Committee on Legal and Constitutional Affairs held a round-table discussion of constitutional academics to receive input on potential areas of constitutional reform (Parliament of the Commonwealth of Australia, 2008, para 6.28).

The NHRC process now under way stems from an election commitment by the government to hold public consultation on the issue of the protection of human rights in Australia. (Note 26) Whether this process leads to the enhancement of human rights protection depends on whether there is shown to be sufficient public support for reform. To address that question one needs to examine the nature of the human rights debate in Australia.

\section{The nature of the human rights debate}

The reasons why the Commonwealth of Australia has not see the enactment of a Bill of Rights during its 108-year history will be examined in turn.

\subsection{Lack of knowledge about constitutional matters}

First, Australians are disengaged from their Constitution, broadly unaware how it works and therefore, perhaps inevitably, fearful of changing what they do not understand. Numerous surveys have confirmed a general lack of knowledge about the Constitution: As Campbell (2001, p. 624) notes:

A survey conducted on behalf of the Constitutional Commission in April 1987 indicated that only 53.9 per cent of those surveyed (approximately 1 100) knew that there is a written federal Constitution. The survey showed that the respondents most aware of the existence and significance of this Constitution were males over the age of 35 years who had left school at 17 years of age or over and who were in full-time employment as white-collar workers. Nearly 70 per cent of the respondents in the 18-24 age group were not even aware of the existence of a written Constitution.

Similarly, a survey taken in 1992 indicated that $33 \%$ of those surveyed were not even aware that a federal Constitution existed, and that this proportion increased to 45\% among those aged between 18 and 24 (Muller, 1992 and Galligan, 1995, p. 129).

\subsection{An anti-theoretical approach}

Undoubtedly linked to disengagement from constitutional matters, the next striking feature of the debate is its anti-theoretical nature, and the absence of consideration of the issues from a jurisprudential perspective. Proponents of either statutory or constitutional (Note 27) protection of human rights have based their case primarily on pragmatic arguments, such as the need to restrain the 'elective dictatorships' which they (correctly) argue that governments have become in the absence of effective parliamentary control, or on the need to address specific human rights abuses, 
particularly those that have occurred in relation to migration law. (Note 28) Valid as these arguments are, they fail to address the fundamental philosophical question of why people are entitled to human rights. Similarly, opponents of a Bill of Rights confine their arguments to pragmatics, such as the question of whether increased protection of human rights would alter the balance between the legislature and the judiciary (Craven, 2004, p. 181-188). Yet valid answers on the question of whether human rights are adequately protected can be reached only if participants in the debate understand the rationale for human rights protection in the first place. Indeed, once that is achieved, pragmatic questions such as what constitutional structures are required to give effect to that rationale are far more easily answered.

There is, of course, a vast array of modern theories of jurisprudence to choose from that offer justifications for a Bill of Rights. Some are sufficiently uncomplicated as to be useable in general public discourse. Perhaps the most useful of these is Rawls' theory of justice (Rawls, 1972, pp. 17-22 and 136-162; Rawls, 1993, pp. 5-7). His hypothesis of what people in what he termed the original position, behind a veil of ignorance, and unaware of what their status would be in the society whose rules they were creating, has the appeal of simplicity and also elicits in those exposed to it an appreciation of the need for law to cater to the uncertainties of life and the situation of the socially vulnerable. (Note 29) Yet proponents of a Bill of Rights have not ventured even to discuss this relatively straightforward school of thought, perhaps because they believe that the Australian public is unfamiliar with theoretical discourse.

Aside from jurisprudential arguments, a principled argument that can be made in favour of a Bill of Rights is the need for Australia to apply domestically what it preaches internationally. Australia has adopted the Universal Declaration on Human Rights, the International Covenant on Civil and Political Rights (ICCPR) and the International Covenant on Social and Economic Rights (ICESR), as well as a host of other human rights documents. By so doing, it has accepted the philosophy underlying the post-World War II human rights movement which, following the proceedings of the Nuremberg and other war crimes courts, as well as those of domestic courts in Germany, rejected the positivist idea that law depended solely on effectiveness for its validity, and instead affirmed that conformity with respect for human dignity and the rights it implies is also required. This body of human rights law forms an international ius commune, from which countries are not exempt simply because they are democracies, yet Australia has failed to enact into its own law the values which, by ratifying these documents, it has prescribed for the rest of the world. Again, these are telling, principled arguments, yet they are rarely articulated in the debate in Australia. The reason for this may in part be that, where law reform is concerned, Australians are not noted internationalists. Thus, arguments based on the need to conform to international law (even international law that Australia has itself helped shape) may result in a backlash against what is seen as an attempt to institutionalise external interference in Australian affairs.

\subsection{Absolute faith in democracy}

If the debate in Australia has not been about principles, what has it been about? Essentially, it has been about democracy and, in particular, the supposed primacy of democracy as a constitutional value and the threat posed to democracy by a Bill of Rights.

The Australian Constitution was the product of conventions attended by elected delegates from each of the colonies. The conventions eventually led to the drafting of the Constitution, which was subsequently enacted by the United Kingdom and approved in each colony by referendum. Convention delegates manifested an aversion to the inclusion of a Bill of Rights into the Constitution for fear that it might be used as a device for intruding upon State legislative power (House of Representatives Standing Committee on Legal and Constitutional Affairs, 2008, para 6.28) and, more relevant in relation to present-day debate, because of a belief that so long as a government was elected democratically, fundamental freedoms would be safe - an idea which of course owed much to the colonists' British heritage (Joseph and Castan, 2006, p. 27).

It is this uncritical faith in democracy that has been the hallmark of the current debate on human rights. Those who oppose a Bill of Rights base their arguments on the proposition that protection of our rights ultimately rests on democracy and that therefore the democratic will should not be subject to control by the judiciary applying a Bill of Rights (Campbell, 2006). Not only is this to misunderstand the nature of rights, but it also exposes a misunderstanding of democracy: Characterising democracy as the supreme value in the legal system logically depends on a more fundamental claim that people have a 'right' to be governed democratically. But what is the source of that right? Obviously, it has to derive from a rights theory superior to democracy itself. In other words, those who claim that democracy is superior to human rights are sawing off the branch upon which their argument hangs. If one does not accept the primacy of rights, then one has no touchstone to which to refer to justify why oligarchy, aristocracy, or dictatorship should be rejected as forms of government. In short, democracy depends on the protection of freedom rather than freedom depending on democracy.

A major plank in the argument against a Bill of Rights has been the claim that by protecting the full range of human rights, excessive power would be given to an unelected judiciary over the elected Parliament and thus, by extension, over the people (Craven, 2004, pp. 184-187). The flaw in this argument is that it falsely portrays the power relationship established by a Bill of Rights as one which vests power in the judiciary to over-ride the will of the people as 
represented by the legislature. In reality, what a Bill of Rights would do is to vest in the individual the power to challenge the majority as represented by the legislature, with the courts acting as neutral umpire between the individual and the majority.

The next argument is that enhancing human rights protection would require the courts to balance competing social interests, which they are ill equipped to do. This ignores the fact that courts in Australia, like courts all over the common law world, apply such tests in many areas of law - for example, in the law of torts - as a matter of course. In other words, the balancing of social interests has been a core function of the judiciary throughout the history of the common law. Furthermore, such tests have been applied by Australian courts in relation to human rights since the case of Adelaide Company of Jehovah's Witnesses $v$ Commonwealth (Note 30) decided in 1943, in which Starke J explicitly stated that given that such rights as are protected by the Constitution are not absolute, courts must inevitably balance them against countervailing legislation.

This leads to the final argument made by opponents of a Bill of Rights, which is that it would vest the courts with extensive new powers to strike down laws. Manifestly this is not correct in view of the fact that Parliament was born subject to the provisions of the Constitution, and has thus always been subject to the power of the courts to declare unconstitutional legislation invalid, including legislation which disproportionately limits such express and implied freedoms as it does protect (discussed in Part 3 above). At most, what a Bill of Rights would do is increase the scope, but certainly not the nature, of the functions discharged by the judicial branch.

There is significant irony in the fact that Australians' suspicion of a Bill of Rights, and their aversion to the granting of review powers to the courts, goes hand in hand with a profound suspicion of politicians, who are held in wide disdain, something which became particularly evident towards the end of the life of the Howard Liberal government, whose Ministers were accused of misleading the public on major issues, particularly in relation to the war in Iraq. (Note 31 ) It is also widely acknowledged that Australia's system of responsible government is dysfunctional: Australia does not use proportional representation for elections to the House of Representatives. This means that politics is dominated by the Liberal-National coalition and the Labor party, who alternate in power and use their Parliamentary majorities to support malfeasant Ministers (Patience, 2002, p. 10). Even the Senate, which is elected using a system of proportional representation, and where minority parties usually hold the balance of power, is ineffectual in ensuring adequate scrutiny of the government. Although the Senate committee system is vibrant, and opposition and minor party use their power on committees to probe the actions of public servants and ministers, (Note 32) and also to set up select (that is, ad hoc) committees to investigate specific controversies, the political reality is that the system is useful only up to a point: Ministers frequently refuse requests by Senate committees to appear before them, and instruct public servants not to do so. The rules of parliamentary privilege require that the whole Senate, and not just a committee thereof, needs to agree to a finding of contempt. (Note 33) This means that the minor parties alone do not have the ability to sanction ministers for defying the Senate - they need the support of one or other of the major parties. Unfortunately this has had the consequence that even when the minor parties and the major opposition party has had a majority in the Senate, the major opposition party has refuse to join in a sanctioning of a minister of the governing party in the House of Representatives (where governments are formed) for fear that the precedent will be used against them when they are in power. (Note 34) The net result is, as several observers have commented, that Australia is, in effect, an elective dictatorship (Hamer, 1994, pp. 174-181). This makes Australian's unqualified faith in democracy all the more puzzling. Why is it, in the face of such overwhelming legislative and executive power, that they do not welcome the prospect of an expansion of justiciable rights?

\subsection{The role of the conservative press}

I would suggest that there are two reasons for this - the first, as stated above, is Australian's lack of knowledge of their Constitution, and consequent fear of change. The second is a skilful campaign by the conservative News Limited press, which takes advantage of these circumstances to foster opposition to a Bill of Rights or indeed any enhancement of human rights protection and diminution of governmental power. News Limited newspapers enjoy a dominant share of the newspaper market in Australia, publishing the leading east coast broadsheet and tabloid newspapers (The Australian and the Daily Telegraph respectively). Their leading columnists on the issue take a stance which is both pugnacious and one-sided, making claims about the Constitution and the effect of a Bill of Rights which are fundamentally erroneous. (Note 35) Prominent among these are the arguments addressed above - the allegation that a Bill of Rights would diminish popular power, that it would give the judiciary with tasks that it cannot discharge and that it would vest the judiciary with novel powers, all of which betray a misunderstanding of the current constitutional situation. This is not to deny that there are not voices which support a Bill of Rights. (Note 36) An important voice has been that of former High Court Justice Michael Kirby, who has spoken and written in support of the incorporation of international human rights norms into domestic law (Kirby, 1999) and the enactment of a charter of rights (Kirby, 2008). The problem is that when significant institutions of the press, with significant power to influence the public with emotive, simplistic and inaccurate argument, are dominant, more reasoned and complex arguments tend to be sidelined. 


\section{Possible outcomes and lessons for civics education}

What then is the likely outcome of the NHRC process? The terms of reference of the NHRC expressly states that the recommendations it produces 'should preserve the sovereignty of the Parliament and not include a constitutionally entrenched bill of rights'. Strictly speaking, the Commonwealth Parliament is not sovereign (in the way that the State Parliaments are), because its capacity is restricted to those legislative topics allocated to it by the Constitution, and subject to the express and implied rights already protected by the Constitution. It is however true that subjecting Parliament to any new rights and freedoms would require constitutional amendment, as ss 1, 23, 40 and 51 of the Constitution prevent the Commonwealth Parliament from placing restraints, either procedural or substantive, on its own legislative power. Thus what the terms of reference do is restrict the NHMRC process from recommending any method of rights protection which would require constitutional amendment.

This does however leaved open a range of options. As stated above, the Australian Capital Territory's Human Rights Act 2004 (ACT) and Victoria's Charter of Rights and Responsibilities Act 2006 (Vic) provide modest protection for human rights in so far as they mandate the courts to interpret statutes in accordance with human rights, where possible. (Note 37) However, these documents are not justiciable in the sense of empowering the courts to strike down legislation which is inconsistent with human rights - indeed, the courts are expressly required to apply legislation notwithstanding its incompatibility. (Note 38)

Far more promising is the model provided by s 10(1) of the Commonwealth's Racial Discrimination Act 1975 (Cth), which in essence states that the Act will apply notwithstanding the provisions of any law which discriminates contrary to the Act. Section 10(1) is constitutional, because the Commonwealth Parliament could simply repeal s 10(1), and can declare it not to be applicable to specific pieces of legislation. (Note 39) The point is, however, that Parliament has to bear the political cost of declaring that it is excluding the operation of the Act.

In this respect, the Racial Discrimination Act 1975 (Cth) is similar in operation to the Canadian Charter of Rights and Freedoms, as laws inconsistent with the Charter can be declared invalid by the courts, (Note 40) but Parliament can over-ride the Charter by declaring that it intends to do so. (Note 41) This is the best model that the NHRC would bed able to recommend, in light of its terms of reference. Although this model ultimately cannot prevent over-ride of rights, it has the strength that it requires politicians to risk the opprobrium that would accompany the required admission that the legislation they are enacting denies fundamental human rights.

Finally, but by no means least importantly, an examination of the human rights debate in Australia reveals the need to enhance civics education, both in schools and in the broader community. Currently, civics education takes a mechanical, rather than a values-based, approach to education about the Constitution. (Note 42) School students are explained the workings of the Constitution, but without being exposed to a critical understanding of democracy, its rationale and its shortcomings. This means that, having no theoretical point of reference against which to evaluate the Constitution as it stands, they are ill-equipped to debate the pros and cons of constitutional reform. (Note 43) It is therefore no surprise that adults are no better informed, as little civics education takes place through the public media. It is therefore clear that, irrespective of the outcome of the current NHRC process, Australia must address the deficit in civics knowledge that it has highlighted, which has provided such fertile ground for constitutional misinformation.

\section{References}

Albrechtsen, J. (2004). 'Wary of a world where new high priests hold sway' The Australian, June 30, 15.

Albrechtsen, J. (2009). 'Crusaders for rights charter rely on lies' The Australian 8 April, 12.

Campbell, E. (2001). Fashioning and Re-fashioning the Constitution. University of New South Wales Law Journal, 24, $620-635$.

Campbell, T. (2006). Does Anyone Win under a Bill of Rights? A Response to Hilary Charlesworth's "Who Wins Under a Bill of Rights"'. University of Queensland Law Journal, 25, 55-63.

Constitutional Commission. (1988). Final Report of the Constitutional Commission. Australian Government Printing Service: Canberra.

Craven, G. (2004). Conversations with the Constitution: Not Just a Piece of Paper, University of New South Wales Press: Sydney.

Davis, M. (2003). Civics Education and Human Rights. Australian Journal of Human Rights, 9, 236 - 255.

Galligan, B. (1995). A Federal Republic - Australia's System of Constitutional Government, Cambridge University Press: Cambridge.

Hamer, D. (1994). Can Responsible Government Survive in Australia?, University of Canberra Press: Canberra.

Hanks, P., Keyzer, P. and Clarke, J. (2004). Australian Constitutional Law - Materials and Commentary, $7^{\text {th }}$ ed, Lexis-Nexis: Chatswood. 
Harris, B. (2002). A New Constitution for Australia, Cavendish Publishing: London.

Harris, B. (2006). Civics Education. Submission to Joint Parliamentary Committee on Electoral Matters, Parliament of the Commonwealth of Australia: Canberra.

House of Representatives Standing Committee on Legal and Constitutional Affairs. (2008). Reforming our Constitution: A roundtable discussion, Parliament of the Commonwealth of Australia: Canberra.

Joseph, S., and Castan, M. (2006). Federal Constitutional Law - A Contemporary View, $2^{\text {nd }}$ ed, Lawbook Co: Pyrmont.

Kingston, M. (2002a). Labor backdown opens black hole of accountability, Sydney Morning Herald On-line, 1 August 2002, available at http://www.smh.com.au/articles/2002/07/31/1027926912621.html.

Kingston, M. (2002b). Labor's latest travesty, Sydney Morning Herald On-line, 23 October 2002, available at http://www.smh.com.au/articles/2002/10/23/1034561546910.html

Kirby, M. (1999). Domestic implementation of international human rights norms. Australian Journal of Human Rights, 5(2), 109-125.

Kirby, M. (2008). An Australian charter of rights - answering some of the critics. Australian Bar Review, 31, $149-158$.

Muller, D. (1992). Most want Constitution changed once they work out what it is. Sydney Morning Herald, 3 July 1992, 6.

Oakes, L. (2002). Hypocritical oath, The Bulletin (Sydney), 13 March 2002, 17.

Pascoe, S. (1999). Education for Active Citizenship. Paper presented at the $50^{\text {th }}$ Anniversary of Australian Citizenship Conference, Melbourne, 21-13 July 1999.

Patience, A. (2002). Ministerial responsibility is now a debauched currency. Canberra Times, 19 February $2002,10$.

Rawls, J. (1972). A Theory of Justice, Oxford University Press: Oxford.

Rawls, J. (1993). Political Liberalism, Columbia University Press: New York.

Riley, M. (2004). Blame Game For a PM On The Backfoot. The Sydney Morning Herald, 13 February $2004,15$.

Robertson, G. (2009). The Statute of Liberty: How to give Australians back their rights, Vintage Books: North Sydney.

Stephen, S. (2002). Refugee drownings: Labor sabotages inquiry, Green Left Weekly, 11 September 2002 , p. 24.

\section{Notes}

Note 1. See the NHRC website at

http://www.humanrightsconsultation.gov.au/www/nhrcc/nhrcc.nsf/Page/Home

Note 2. Section 106 of the Commonwealth Constitution preserves the existence of the State (formerly colonial) Constitutions, while s 107 says that, subject to the Constitution, the State Parliaments continue to enjoy the same legislative powers they had prior to federation.

Note 3. Note, however, that this is subject to each of the original six States (and no more have been created) having a guaranteed minimum representation of five seats.

Note 4. Commonwealth Constitution, s 53.

Note 5. Section 122.

Note 6. Under the Northern Territory Self-Government Act 1978 (Cth) and the Australian Capital Territory Self-Government Act 1988 (Cth) respectively.

Note 7. Voters in the Territories are counted for national majority purposes but are irrelevant to the 'majority in a majority of States' requirement.

Note 8. Joseph, S., and Castan, M. (2006). Federal Constitutional Law - A Contemporary View, $2^{\text {nd }}$ ed, Lawbook Co: Pyrmont, p. 26.

Note 9. Sections 52, 90 and 122.

Note 10. The exclusive powers of the Commonwealth relate to laws relating to Commonwealth places (s 52(i)), the Commonwealth public service (s 52(ii)), defence (s 114), and coinage (s 115).

Note 11. (1920) 128 CLR 129.

Note 12. See, for example, Fairfax v Commissioner of Taxation (1965) 114 CLR 1 and Northern Suburbs General Cemetry Reserve Trust v Commonwealth (1993) 176 CLR 555.

Note 13. New South Wales v Commonwealth (Work Choices Case) (2006) 229 CLR 1. 
Note 14. Australian Capital Television v Commonwealth (No 2) (1992) 177 CLR 106.

Note 15. Roach v Electoral Commissioner (2007) 223 CLR 162.

Note 16. Derived from s 75(v) of the Constitution, as interpreted in Chu Kheng Lim v Minister for Immigration and Multicultural Affairs (1992) 176 CLR 1.

Note 17. Attorney-General (NSW) v Trethowan (1931) 44 CLR 395.

Note 18. Sex Discrimination Act 1974 (Cth); Racial Discrimination Act 1975 (Cth); Disability Discrimination Act 1992 (Cth).

Note 19. Northern Territory National Emergency Response Act 2007 (Cth), s 132.

Note 20. Section 30 (ACT), s 32 (Vic).

Note 21. Section 32(3) (ACT), s 36(5) (Vic).

Note 22. Section 32(2) (ACT), s 32(2) (Vic).

Note 23. Section 40B (ACT), s 38 (Vic).

Note 24. Section 40C(4) (ACT), s 39(3) (Vic).

Note 25. G.A. Res. 2200 A (XXI), 16 December 1966.

Note 26. See the statement by the Attorney-General at

http://www.humanrightsconsultation.gov.au/www/nhrcc/nhrcc.nsf/Page/Who_AMessagefromtheAttorney-GeneraltheH onRobertMcClelland

Note 27. It should be noted that the NHRC's Terms of Reference specifically exclude the option of a 'constitutionally entrenched bill of rights (see

http://www.humanrightsconsultation.gov.au/www/nhrcc/nhrcc.nsf/Page/Terms_of_Reference).

Note 28. For example, the cases of Vivian Alvarez Solon, deported from Australia by purely administrative process, and of Cornelia Rau, held in immigration detention, again through executive action without any statutory requirement of judicial approval, highlighted the need for the better protection of procedural rights when a person is deprived of liberty.

Note 29. Rawls postulated what fundamental rules a group of people would draft if in what he called the original position', behind a 'veil of ignorance' - that is, unaware of what their race, gender, ethnicity, social or financial position would be in the society they were drafting rules for. Rawls' conclusion was that this rational process would lead to the adoption of two key principles: (i) that each person should have an equal right to the most extensive scheme of equal basic liberties compatible with a similar scheme of liberties for others and (ii) that social and economic inequalities should be arranged in such a way as to be of the greatest benefit to the least-advantaged members of society.

Note 30. (1943) 67 CLR 116.

Note 31. An opinion poll conducted in 2003 found that $70 \%$ of Australians believed that the then government had misled the public on intelligence justifications for the war (Riley, 2004, p. 15).

Note 32. Particularly important in this regard are the biennial 'estimates hearings' by the standing committees which have responsibility for oversight of various portfolio areas. These hearings are nominally conducted for the purpose of reviewing the effectiveness and efficiency of government expenditure, but the committees consider themselves at large to inquire into any aspect of departmental or ministerial conduct, since this all depends on a vote of money by Parliament.

Note 33. Hamsher $v$ Swift (1992) 33 FCR 545 at 563-64, Television New Zealand Ltd v Prebble [1993] 3 NZLR 513 (CA) at 528, 536 and 540; Prebble $v$ Television New Zealand Ltd [1994] 3 NZLR 1 (PC) at 9.

Note 34. The most striking example of this occurred in 2002, when it became clear that a minister in the then Liberal government had lied about when he was informed by defence force personnel that the government's allegation that refugees had thrown their children off rafts in order to be allowed to land in Australia (the 'Children Overboard' affair). The opposition Labor party refused to join the minor parties in a motion to summons the minister to appear before the committee and to sanction him if he did not - see Oakes (2002, p. 17); Kingston (2002a, and 2002b) and Stephen (2002 p. 24).

Note 35. For frequent and vigorous criticism of a Bill of Rights in the press see articles by Janet Albrechtsen, for example Albrechstsen (2004, p.15) and Albrechsten (2009, p.12).

Note 36. See for example Robertson (2009).

Note 37. Section 30 (ACT), s 32 (Vic). 
Note 38. Section 32(3) (ACT), s 36(5) (Vic).

Note 39. As indeed was done in controversial circumstances when, in enacting laws giving the government power inter alia to manage welfare income received by Aboriginal people in a manner differently from welfare received by non-Aboriginal people, Parliament expressly excluded the operation of s 10(1) of the Racial Discrimination Act in relation to those laws (see the Northern Territory National Emergency Response Act 2007 (Cth), s 132).

Note 40. Section 24.

Note 41. Section 33(1).

Note 42. See Harris (2006).

Note 43. See, generally, Pascoe (1999) and, with specific reference to the debate on human rights, Davis (2003). 